\title{
A Literature Review on the Unified Power Flow Controller UPFC
}

\author{
Ahmed Nasser Alsammak, PhD \\ Assistance Professor in University of Mosul \\ College of Engineering \\ Electrical Engineering Dept. \\ Mosul-Iraq
}

\author{
Hasan Adnan Mohammed \\ Assistance Lecturer in University of Mosul \\ College of Engineering \\ Electrical Engineering Dept. \\ Mosul-Iraq
}

\begin{abstract}
Power electronic controllers for a flexible ac transmission system (FACTS) can offer a greater control of power flow, secure loading and damping of power system oscillations. A unified power flow controller (UPFC) is a one of FACTS elements that can provide VAR compensation, line impedance control and phase angle shifting. The UPFC consist of two fully controlled inverters, series inverter is connected in series with the transmission line by series transformer, whereas parallel inverter is connected in parallel with the transmission line by parallel transformer. The real and reactive power flow in the transmission line can be controlled by changing the magnitude and phase angle of the injected voltage produced by the series inverter. The basic function of the parallel inverter is to supply the real power demanded by series inverter through the common dc link. The parallel inverter can also generate or absorb controllable reactive power. This paper offers and discusses most papers that used a UPFC to improving the active and reactive power flow of the power systems.
\end{abstract}

\section{General Terms}

This paper terms on the mathematical and practical calculations for a control technique and the circuit outcomes for 50 references.

\section{Keywords}

FACTS Devices, UPFC, Voltage Stability, Power Flow Improvement.

\section{INTRODUCTION}

Last year, the high quality of electric power has become more significant for electric utilities and customers. Utility and customer-side disturbances result in terminal voltage fluctuations, transients, and waveform distortions on the electric grid that finally gives a problem in power quality. Power Quality (PQ) refers to "maintaining the waveforms of voltages and currents as sinusoidal at rated frequency and magnitude". Recently power systems maintaining power quality became most important issue due to the introduction of equipment's with power electronic devices which are more sensitive to power quality problems.

Power Quality is mainly affected by the increased use of nonlinear loads such as power electronic equipment, variable speed drives, electronic control gears etc. Poor power quality can affect the safe, reliable and efficient operation of the equipment. Various aspects of power quality are voltage sag, voltage swell, voltage fluctuations, voltage unbalance, harmonics etc. For power-quality improvement, the development of power electronic devices such as Flexible AC Transmission Systems (FACTS) and custom power devices have introduced an emerging branch of technology providing the power system with versatile new control capabilities [1].

To provide cheaper electricity, present power system is deregulated, under which power is produced by separate generation, transmission and distribution system. Electric power demand is growing day by day. Thus it is necessary to rely on utilization of existing generating unit and to load the existing transmission line to their thermal limits and to maintain stability also. It is also necessary to operate power system with minimum loss in the transmission line. Flexible AC Transmission System (FACTS) devices play an important role in controlling power and enhancing the usable capacity of existing lines. FACTS devices use power electronic component to enhance controllability and increase power transfer capability. Future electric transmission system can be smart by using FACTS devices. FACTS controller includes Static Synchronous Compensator (STATCOM), Thyristor Controlled Series Capacitor (TCSC), Static Series Synchronous Compensator (SSSC), Static VAR Compensator (SVC), which are capable of controlling the network condition in a very fast manner to improve voltage stability and power quality. When the system is unable to meet the reactive power demand, voltage instability occurs in the power system. Reactive power imbalance occur when the system is faulted, heavily loaded and voltage fluctuation is there. Reactive power balance can be done by using FACTS devices in the transmission line, which can inject or absorb reactive power in the system as per requirement [2].

FACTS has number of benefits, such as greater power flow control, increased secure loading of existing transmission lines, damping of power oscillations, less environmental impact and potentially less cost than most alternative techniques of transmission system reinforcement.

The UPFC is the most versatile of the FACTS devices. It performs the functions of the static synchronous compensator (STATCOM), thyristor switched capacitor (TSC) thyristor controlled reactor (TCR), and the phase angle regulator. Further, it also provides additional flexibility by combining some of the functions of the said controllers.

The main function of the UPFC is to control the flow of real and reactive power by injecting voltage in series with the transmission line. Both the magnitude and the phase angle of the voltage can be varied independently. Real and reactive power control allows power flow in prescribed routes and loading of transmission lines closer to their thermal limits. UPFC's are also used for improving transient and small signal stability of the power system. The schematic diagram of the UPFC is shown in Figure 1 [3].

The unified power flow controller (UPFC) is a combination of three compensator's characteristics, i.e. impedance, voltage 
magnitude and phase angle, that are able to produce a more complete compensation. By controlling impedance, voltage magnitude, phase angle. Unified power flow controller (UPFC) is used to control the power flow in the transmission systems. The UPFC consists of two voltage source converters; series and shunt converters, which are connected to each other with a common dc link. Shunt converter or Static Synchronous Compensator (STATCOM) is used to provide reactive power to the ac system, besides that, it will provide the $\mathrm{dc}$ power required for both inverters, while series converter or Static Synchronous Series Compensator (SSSC) is used to add controlled voltage magnitude and phase angle in series with the line. Each of the branches consists of a transformer and power electronic converter. These two voltage source converters shared a common dc capacitor. The energy storing capacity of this dc capacitor is generally small. Therefore, active power drawn by the shunt converter should be equal to the active power generated by the series converter. The reactive power in the shunt or series converter can be chosen independently, giving greater flexibility to the power flow control. The coupling transformer is used to connect the device to the system [4].

This paper presents a sum of papers that used a UPFC to improving the active and reactive power flow of the power systems.

\section{UPFC LITERATURE REVIEW:}

By using power electronic controllers a flexible ac transmission system (FACTS) can offer greater control of power flow, secure loading and damping of power system oscillations. The FACTS refers to power electronic systems such as the static VAR compensator (SVC), thyristor controlled series capacitor (TCSC), static condenser (STATCON) and unified power flow controller (UPFC). A unified power flow controller is a power electronic system which can provide VAR compensation, line impedance control and phase angle shifting. The UPFC consists of two fully controlled power electronic converters as illustrated in Figure 1 inverter 2 is connected in series with the transmission line by transformer $\mathrm{T} 2$, whereas Inverter 1 is connected in parallel with the transmission line by transformer TI. The real and reactive power flow in the transmission line can be quickly regulated by changing the magnitude and phase angle of the injected voltage produced by Inverter. The basic function of Inverter 1 is to supply the real power demanded by Inverter 2 through the common dc link. Inverter 1 can also generate or absorb controllable reactive power [5].

In (1994) Laszlo Gyugyi and Fellow described a novel approach in which solid-state synchronous voltage sources are employed or the dynamic compensation and real time control of power flow in transmission systems. The synchronous voltage source is implemented by a multi-pulse inverter using ate turn-off (GTO) thyristors. It is capable of generating internally the reactive power necessary for network compensation, and is also able to interface with an appropriate energy storage device to negotiate real power exchange with the ac system. They develops a comprehensive treatment of power flow control using solid-state synchronous voltage sources for shunt compensation, series compensation, and phase angle control. It also describes the unique unified power flow controller that is able to control concurrently or selective all three network parameters (voltage, impedance, transmission angle) determining power transmission [6]

In 1995 Gyqyi, and et al. described the basic concepts of the proposed generalized $\mathrm{P}$ and $\mathrm{Q}$ controller and compares it to the more conventional, but related power flow controllers, such as the thyristor-Controlled Series Capacitor and Thyristor-Controlled Phase Angle Regulator. And they also present results of computer simulations showing the performance of the UPFC under different system conditions [7].

In (1996) Round, and et al. studied the performance of a unified power flow controller (UPFC) with four different controllers and evaluated through simulation and implementation in an experimental laboratory model. The controllers which were investigated are the PI controller, PI controller with decoupling, cross-coupling controller and robust $\mathrm{H} \infty$ controller. It is found that the cross- coupling and Robust $\mathrm{H} \infty$ controllers have the best performance when the exact value of the power transmission parameters is unknown [8].

In (1997) M. Noroozian, et al. deal with optimal power flow control in electric power systems by use of unified power flow controller (UPFC). And they developed and analyzed Models suitable for incorporation in power flow programs. And demonstrated the application of UPFC for optimal power flow control through numerical examples. It is shown that a UPFC has the capability of regulating the power flow and minimizing the power losses simultaneously [9].

In (2000) Zhengyu Huang, et al. discuss four principal main control strategies and the computer tests results support the discussion conclusion and also they concluded the constant power flow control is good for steady state control and the constant series compensation control is useful for first swing stability. The supplementary control is very efficient in damping the power oscillation. The suggested UPFC control can realize the desired control strategy flexibly and improve system dynamic performance significantly [10].

In (2010) Muthukrishnan and Nirmal Kumar dialed with digital simulation and implementation of power system using UPFC to improve the power quality. They deduce that UPFC is also capable of improving transient stability in a power system [11].

In (2010) Mathukrishanan and nirmalkumar dialed with digital simulation of 14 - bus power system using UPFC to improve the power quality, they conclude that the UPFS has the capability of improving the transient stability in a power system [12].

In (2010) Murali, and et al. investigates the improvement of transient stability of a two-area power system using UPFC and simulations are carried out in Matlab/Simulink environment for the two-area power system model with UPFC to analyze the effects of UPFC on transient stability performance of the system. The performance of UPFC is compared with other FACTS devices such as Static Synchronous Series Compensator (SSSC), Thyristor Controlled Series Capacitor (TCSC), and Static Var Compensator (SVC) respectively. The simulation results demonstrate the effectiveness and robustness of the proposed UPFC on transient stability improvement of the system [13]. In (2011) Arup Ratan Bhowmik and Champa Nandi investigated the performance of Unified Power Flow Controller (UPFC) in controlling the flow of power over the transmission line and they dialed with digital simulation of standard IEEE 14-bus power system using UPFC to improve the real and reactive power flow control through a transmission line by placing UPFC at the sending end using computer simulation [14].

In (2012) Aarti Rai includes first the optimal location of FACTS devices, second voltage stability analysis and third 
control of reactive power of system. The model can be simulated in MATLAB. The performance of the whole system such as voltage stability, transient stability, frequency and power swings will be analyzed and compared without FACTS and with FACTS device [15].

In (2013) Rama Sekhara Reddy and Vijaya Kumar used a Unified Power Flow Controller (UPFC) to control the power flow in the transmission systems by controlling the impedance, voltage magnitude and phase angle in wind energy generation. This controller offers advantages in terms of static and dynamic operation of the power system [16].

In (2013) Hakim Elahi Tooraji and Nekoubin Abdolamir designed and simulated a Unified Power Flow Controller is in multi-machine power system. The on-line designed process is based on PWM method which all the power quality parameters representing as voltage sag and sweel can be improved. In the proposed control method, the harmonic distortion of the system is decreased and the voltage oscillations of the DC capacitor will be improved. Simulations that are done by the PSCAD/EMTDC software show the effectiveness and precision of this designing as shown in Figure 2 [17].

In (2013) Kumar Gaurav and Nitin Saxena investigate the enhancement in voltage stability margin as well as the improvement in the power transfer capability in a power system with the incorporation of UPFC. A simple transmission line system is modeled in Matlab/Simulink environment. The load flow results are first obtained for an uncompensated system, and the voltage and power profiles are studied. The results so obtained are compared with the result obtained after compensating the system using UPFC to show the voltage stability margin enhancement [18].

In (2013) Vaibhav S Kale et, al. proposed the real, reactive power and voltage control through a transmission line by placing UPFC at the sending end using computer simulation. The control scheme has the fast dynamic response and hence is adequate for improving transient behavior of power system after transient conditions [19].

In (2013) K.Ravichandrudu and et al. introduced the concept of Distributed FACTS (D-FACTS) as an alternative approach to realizing cost-effective power flow control. They concluded that the UPFC is capable of improving transient stability in a power system and it is the most complex power electronic system for controlling the power flow in an electrical power system. The circuit model is developed for UPFC using rectifier and inverter circuits. The control angle is varied to vary the real and reactive powers at the receiving end [20].

In (2013) K.Ravichandrudu et, al. demonstrated the performance of the UPFC in achieving harmonic mitigation and stability of the wind energy grid connected system by using MATLAB/SIMULINK [21].

In (2014) B.Gopinath et, al. proposed a method based on Model predictive control (MPC) and using Bacterial Forging Algorithm (BFA) for modeling Unified Power Flow Controller. Modeling of UPFC is designed with its unique capability to control simultaneously real and reactive power flows on a transmission line as well as to regulate voltage at the bus where it is connected. Therefore this device creates a remarkable quality impact on power system stability. UPFC with additional PI controller is used along with the UPFC main controller for this purpose. The simulation is carried out in MATLAB/simulink [22].

In (2014) Sai Lakshmiet et, al. observed the capability of
DPFC for the transmission line based on PI and fuzzy logic controllers (FLC). On comparing the two controllers performance, so can say that Fuzzy Logic Controller based DPFC gives better compensation than PI Controller based DPFC. Matlab/Simulink is used to create the PI and FLC and to simulate DPFC model [23].

In (2015) Koganti et, al. studied Power quality and stability improvement of HVDC transmission System using UPFC for Different uncertainty conditions, they concluded that UPFC improves the system performance. It can control the power flow in the transmission line, effectively. With the addition of UPFC, the magnitude of fault current reduces and oscillations of excitation voltage also reduce. The total harmonic distortion (THD) is also reduced well below the IEC standards. It is more economical for the HVDC transmission system to transfer more power [24].

In (2015) Shantha Soruban et, al. proposed an ANN based control scheme for a UPFC to be used as an active power filter. The objective is to guarantee power to the load at the required power quality. The ANN control unit monitors the voltage at the point of common coupling. UPFC enables improved power quality by maintaining power factor nearer to unity rapid response time, the ability to provide reactive power at low voltage and to provide voltage compensation can be obtained. For unbalanced voltage compensation, two unbalanced controllers using the phase voltage amplitude and negative sequence component are proposed [25].

In (2015) G.Srinivas and T.Santosh Chaitanya studied and analyzed the operation and performance of D-STATCOM to compensate the harmonics coming from grid side inverter and different loads in that most of the unbalanced and +nonlinear loads injects harmonic currents to source side and effects the source. This can be overcome by using D-STATCOM by connecting as shunt at the distribution side by means of a tie reactance connected to compensate the load current [26]. Table 1 offers a samples of UPFC works, control technique its objectives.

This paper presents a sum of papers that used a UPFC to improving the active and reactive power flow of the power systems.

\section{CONCLUSION}

The real and reactive power flow in the transmission line can be controlled by changing the magnitude and phase angle of the injected voltage produced by the series inverter. The basic function of the parallel inverter is to supply the real power demanded by series inverter through the common dc link. The parallel inverter can also generate or absorb controllable reactive power. The aims of this paper, to study and analyze most researches that topics cover the unified Power flow controller (UPFC) and made a comparison between them in order to improve its functions in addition to obtain a best controlling method for active and reactive power flow of the power system, where this paper offered most papers that used a UPFC to carrying out the following point after finding an optimal location of the FACTs device:

1- Improving the active and reactive control power flow of the power systems.

2- Increasing the transient stability,

3- Increasing the damping of sub synchronous resonance.

4- Controlling the steady state or dynamic performance.

5- Optimizing power flow. 
6- Minimizing the operational costs of the electrical grid.

Finally, when a comparison doing with the other FACTs devices it can concluded that UPFC is more dynamic stability, and it is a better way to control the active and reactive power flow with low cost and high reliability. FACTS are powerful strategies to improve the voltage waveform and power quality enhancement. It is founded also that the performance of the UPFC is more effective for the improving power system as compared with the other FACTS devices such as SVC, TCSC, and SSSC respectively.

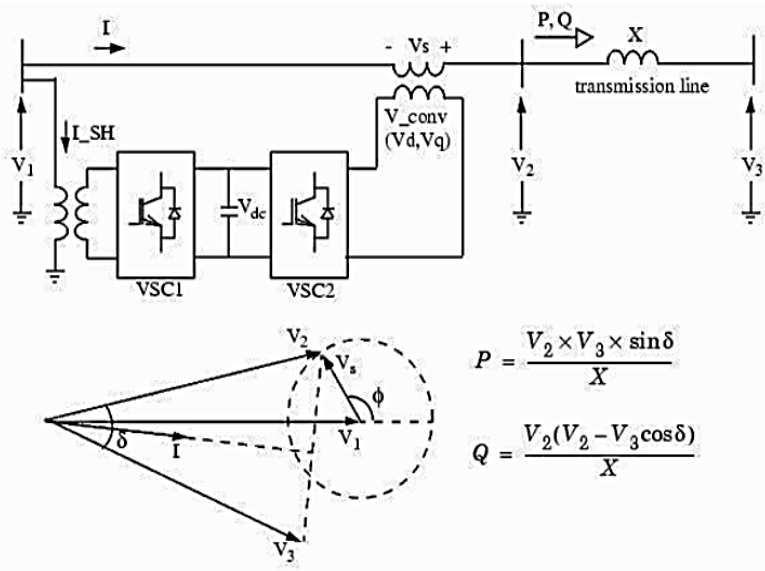

Fig.1: Schematic diagram of the UPFC

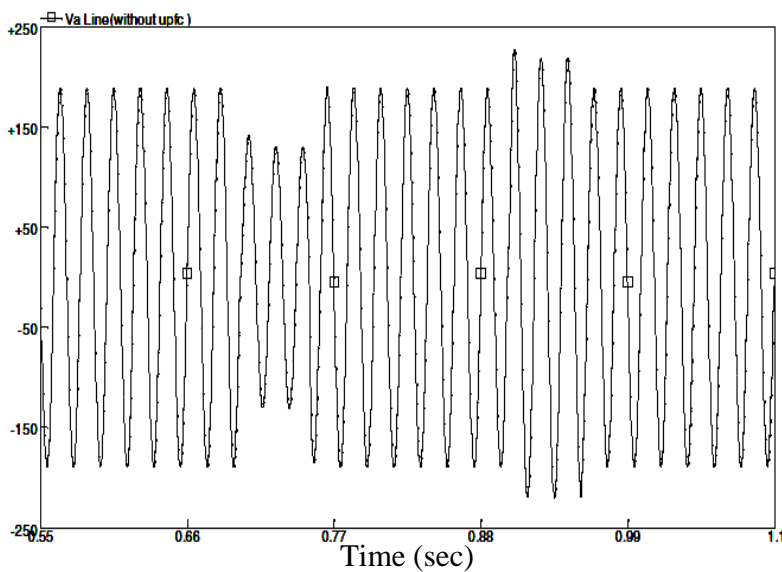

(a)

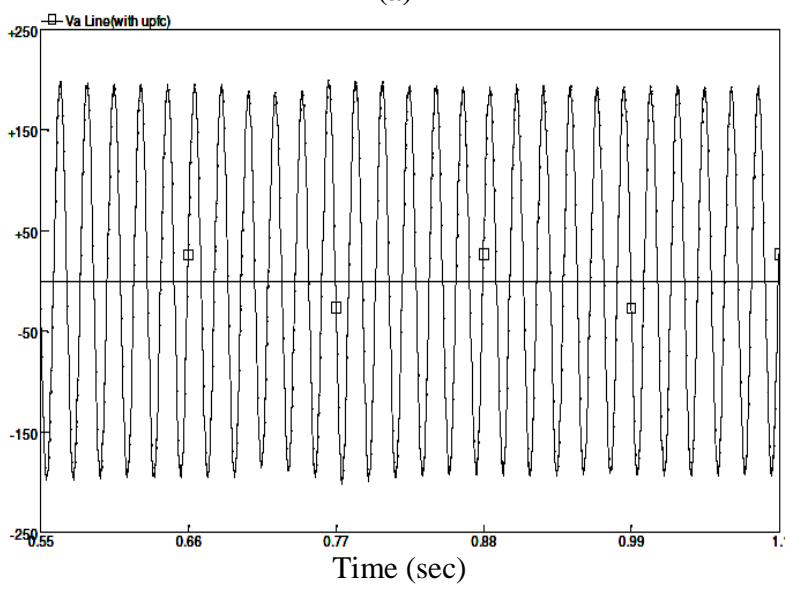

(b)

Fig.2: The experimental results for voltage sag and swell in phase A [17], where: (a) Before connection of UPFC. (b) After connection of UPFC

Table 1: A samples of UPFC works, control technique its objectives

\begin{tabular}{|c|c|c|l|l|}
\hline No. & Year & Ref. No. & \multicolumn{1}{|c|}{ Control Technique } & \multicolumn{1}{|c|}{ The Circuit Outcomes } \\
\hline 1 & 1991 & {$[27]$} & $\begin{array}{l}\text { Using Radial Basis Function Neural Network } \\
\text { (RBFNN) }\end{array}$ & Controlling the active and reactive power flow \\
\hline 2 & 1992 & {$[28]$} & $\begin{array}{l}\text { By analyzing the steady state and dynamic model } \\
\text { of UPFC }\end{array}$ & Controlling the active and reactive power flow \\
\hline 3 & 1993 & {$[29]$} & sliding mode control & Controlling the active and reactive power flow \\
\hline 4 & 1994 & {$[30]$} & Using Artificial Neural Network ANN Strategy & Controlling the active and reactive power flow \\
\hline 5 & 1995 & {$[31]$} & Using the external control & $\begin{array}{l}\text { Increasing the transient stability, or sub } \\
\text { synchronous resonance dampening and } \\
\text { delivers the middle control set points }\end{array}$ \\
\hline 6 & 1996 & {$[32]$} & Using Proportional Integral (PI) Controller & \begin{tabular}{l} 
Realized a low control bandwidth \\
\hline 7
\end{tabular} \\
\hline 8 & 1997 & {$[33]$} & $\begin{array}{l}\text { The in-phase and the quadrature-voltage } \\
\text { components }\end{array}$ & $\begin{array}{l}\text { Controlling the real and reactive power flow of } \\
\text { UPFC. }\end{array}$ \\
\hline 9 & 1997 & {$[35]$} & $\begin{array}{l}\text { Using middle-level power-flow controllers for } \\
\text { UPFC used direct control }\end{array}$ & $\begin{array}{l}\text { Optimizing power flow and increasing the } \\
\text { peransient stability }\end{array}$ \\
\hline 10 & 1997 & {$[36]$} & Using Decoupling control & Controlling the active and reactive power flow \\
\hline
\end{tabular}




\begin{tabular}{|c|c|c|c|c|}
\hline 11 & 1998 & [37] & Using the Proportional and Integral (PI) controller & Improving the transient stability of the system \\
\hline 12 & 1998 & {$[38]$} & Using Mamdani type fuzzy controller & Controlling the active and reactive power flow \\
\hline 13 & 1999 & [39] & Using Cross-coupling control with direct control & Enhance system performance \\
\hline 14 & 2000 & {$[40]$} & Using Higher level control techniques & $\begin{array}{l}\text { Optimizing power flow and increasing the } \\
\text { transient stability }\end{array}$ \\
\hline 15 & 2000 & {$[41]$} & Using de-coupled control & Controlling the active and reactive power flow \\
\hline 16 & 2001 & [42] & Using genetic algorithm & Optimal location of the FACTs device \\
\hline 17 & 2002 & {$[43]$} & $\begin{array}{l}\text { Using current limiting method using the leakage } \\
\text { inductance of series transformer }\end{array}$ & Limiting the fault current of the UPFC \\
\hline 18 & 2004 & {$[44]$} & $\begin{array}{l}\text { Using real and reactive power coordination } \\
\text { controller for a (UPFC) }\end{array}$ & $\begin{array}{l}\text { To avoid instability/loss of DC link capacitor } \\
\text { voltage during transient conditions }\end{array}$ \\
\hline 19 & 2008 & [45] & Using security-constrained re-dispatching model & Resolve system congestion and security issues \\
\hline 20 & 2009 & {$[46]$} & Using MOPSO FACTS device & Congestion management in planning stage \\
\hline 21 & 2010 & {$[47]$} & $\begin{array}{l}\text { In phase voltage adjustment } \\
\text { quadrature voltage adjustment } \\
\text { shunt compensation }\end{array}$ & $\begin{array}{l}\text { Controlling power flow to a multi-machine } \\
\text { Infinite bus system }\end{array}$ \\
\hline 22 & 2011 & [48] & Using Hybrid PSO and a SQP method & $\begin{array}{l}\text { Allocating the FACTS device and optimizing } \\
\text { the objective function of the FACTs device }\end{array}$ \\
\hline 23 & 2012 & [49] & $\begin{array}{l}\text { Using direct power control, based on instantaneous } \\
\text { power theory }\end{array}$ & Controlling the active and reactive power flow \\
\hline 24 & 2016 & {$[50]$} & $\begin{array}{l}\text { Using Newton Raphson algorithm for load flow } \\
\text { studies }\end{array}$ & $\begin{array}{l}\text { minimizing the operational costs of the } \\
\text { electrical grid by choosing Optimal location } \\
\text { for the UPFC }\end{array}$ \\
\hline
\end{tabular}

\section{ACKNOWLEDGMENTS}

Our thanks to all supported colleagues in my department.

\section{REFERENCES}

[1] S. Asha Kiranmai, M. Manjula and V.R.S. Sarma, "Mitigation of Various Power Quality Problems Using Unified Series Shunt Compensator in PSCAD/EMTDC," 16th National Power Systems Conference, 15th-17th Dec. 2010.

[2] D. Mohanty, A, Ahamad, and M. A Khan, "Modeling, Simulation and Performance Analysis of FACTS Controller in Transmission line," International Journal of Emerging Technology and Advanced Engineering, Vol. 3, No. 5, pp. 429-435, May. 2013.

[3] V. Mathad, F. R. Basanagouda, and S. H. Jangamshetti, "Voltage Control and Power System Stability Enhancement using UPFC," International Conference on Renewable Energies and Power Quality (ICREPQ'14), Apr. 2014, Vol.1, No.12, pp. 871-875.

[4] S. S. Khonde, S. S. Dhamse, and A. G Thosar, "Power Quality Enhancement of Standard IEEE 14 Bus System using Unified Power Flow Controller," International Journal of Engineering Science and Innovative Technology (IJESIT), Vol. 3, No. 5, pp. 323-334, Sept. 2014.

[5] Q. Yu, L. Norum, T. Undelan, and S. Round "Investigation of Dynamic Controllers for a Unified Power Flow Controller,” IEEE, pp. 1764-1769, 1996.

[6] L. Gyugyi \& Fellow, "DYNAMIC COMPENSATION OF AC TRANSMISSION LINES BY SOLID-STATE SYNCHRONOUS VOLTAGE SOURCES," IEEE
Transactions on Power Delivery, Vol. 9, No. 2, pp. 904 911, Apr. 1994

[7] L. Gyqyi, T. R. Rietman, A. Edris, C. D. Schauda, s. L . Willirms, and , D.R. Torgerson, "THE UNIFIED POWFBFLOW CONTROLLER: A NEW APPROACH TO POWER TRANSMISSION CONTROL," IEEE Transactions on Power Delivery, Vol. 10, No. 2, pp. 1085-1097, Apr. 1995

[8] Q. Yu, S. D. Round, L. E. Norum, and T. M. Undeland, "Dynamic Control of a Unified Power Flow Controller," IEEE, pp. 508-514, 1996.

[9] M. Noroozian, L, Angquist, M. Ghandhari and G. Anderson, "USE OF UPFC FOR OPTIMAL POWER FLOW CONTROL," IEEE Transactions on Power Delivery, Vol. 12, No. 4, pp.1629-1634, Oct. 1997.

[10] Z. Huang, Y. Ni, , C. M. Shen, F. W. Felix, S. Chen and B. Zhang, "Application of Unified Power Flow Controller in Interconnected Power Systems-Modeling, Interface, Control Strategy, and Case Study," IEEE Transactions on Power systems, Vol. 15, No. 2, pp. 817 824, May. 2000.

[11] S. Muthukrishnan and A. Kumar, "Comparison of Simulation and Experimental Results of UPFC used for Power Quality Improvement," International Journal of Computer and Electrical Engineering, Vol. 2, No. 3, pp. 555-559, June. 2010.

[12] S. Muthukrishnan and A. Kumar, "Enhancement of power Quality in 14 Bus System Using UPFC," Research journal of Applied Sciences, Engineering and technology," ISSN. 2040-7467, pp. 356-361, July. 2010. 
[13] D. Murali, M. Rajaram and N. Reka, "Comparison of FACTS Devices for Power System Stability Enhancement," International Journal of Computer Applications, Vol.8, No.4, pp.30-35, Oct. 2010.

[14] A. R. Bhowmik and C. Nandi, "Implementation of Unified Power Flow Controller (UPFC) for Power Quality Improvement in IEEE 14-Bus System," Arup Ratan Bhowmik et al, Int. J. Comp. Tech. Appl., Vol. 2 (6),1889-1896, 2011.

[15] A. Rai, "Enhancement of Voltage Stability \& reactive Power Control of Distribution System Using Facts Devices," International Journal of Scientific Research Engineering \& Technology, Vol.1, No. 9, pp. 001-005, Dec. 2012.

[16] M R. S. Reddy and M. V. Kumar, "Power Quality Improvement in DFIG based Wind Energy Conversion System using UPFC," IOSR Journal of Engineering (IOSRJEN) Vol. 3, No. 1, pp. 46-54, Jan. 2013.

[17] H. E. Tooraji and N. Abdolamir, "Improving Power Quality Parameters in AC Transmission Systems Using Unified Power Flow Controller," Research Journal of Recent Sciences, Vol.2, No.4, pp.84-90, Apr. 2013.

[18] K. Gaurav and N. Saxena, "Power Quality improvement using UPFC," International Journal of Electrical, Electronics and Computer Engineering, Vol.2, No.2, pp. 30- 33, 2013.

[19] S. Vaibhav Kale, R. P.Prashant and R. Khatri, "Unified Power Flow Controller for Power Quality Improvement," International Journal of Emerging Science and Engineering (IJESE), Vol.1, No. 10, pp. 1-4, Aug. 2013.

[20] K. Ravichandrudu, P. Raghava Rani, P. Yohan babu, and G.V.P. Anjaneyulu, "Comparison of Simulation Results of D-Facts \& UPFC Used for Power Quality Improvement," International Journal of Scientific and Research Publications, Volume 3, No. 9, pp. 1-5, Sept. 2013.

[21] K. Ravichandrudu, P. S. Pramod Kumar, and, V.E. Sowjanya, "MITIGATION OF HARMONICS AND POWER QUALITY IMPROVEMENT FOR GRID CONNECTED WIND ENERGY SYSTEM USING UPFC," International Journal of Application or Innovation in Engineering \& Management (IJAIEM), Vol. 2, No. 10, pp. 141-156 Oct. 2013.

[22] B. Gopinath, N. Vinothini, and S. kumar, "Modeling of UPFC Using Model Predictive Control and Bacterial Foraging Algorithm," International Journal of Innovative Research in Computer and Communication Engineering, Vol. 2, No. 1, pp. 2724-2731, Jan. 2014.

[23] K S. Lakshmi, G. Ujwala, and K. R. Reddy, "MITIGATION OF VOLTAGE SAG AND SWELL FOR POWER QUALITY IMPROVEMENT USING DISTRIBUTED POWER FLOW CONTROLLER'," International Journal Of Professional Engineering Studies, Vol. 2, No. 4, pp. 78-84, July. 2014.

[24] K. S. Lakshmi, G. Sravanthi, L. Ramadevi, and K. H. Chowdary, "Power quality and stability improvement of HVDC transmission System using UPFC for Different uncertainty conditions," International Journal of Scientific \& Engineering Research, Vol. 6, No. 2, pp. 795-801, Feb. 2015.
[25] M. S. Soruban, J D. Sathyaraj, and J. J. Gnana Chandran, "Power Quality Enhancement Using UPFC as an Active Power Filter for Renewable Power Generation," International Journal of Advanced Research in Electrical, Electronics and Instrumentation Engineering Vol. 4, No. 3, pp. 1712-1718, March. 2015.

[26] G. Srinivas and T. Santosh Chaitanya, "Enhancement of Power Quality Using FACTS Devices (D-STATCOM)," International Journal of Advanced Research in Electrical, Electronics and Instrumentation Engineering, Vol. 4, No. 4, pp. 1956-1965, Apr. 2015.

[27] S. Chem, C. F. N. Cown, and P. G. Grant, "Orthogonal Least Squares Learning Algorithm for Radial basis Function Networks," IEEE Transactions on neural Network, 2, p 302, 1991.

[28] L. Gyugyi, "A Unified Power Flow Control Concept for Flexible AC Transmission Systems," IEE Proceedings-C , Vol. 139, No. 4, p. 323-331, 1992.

[29] J. Hung, W. Gao, and J. Hung, "Variable structure control: A survey," IEEE Trans. Ind. Electron., Vol. 40, No. 1, pp. 2-22, Feb. 1993.

[30] H. Desmuth MATLAB Users Guide Neural Network Tool Box. The MathWork Inc, 1994.

[31] L. Gyugyi, C. Schauder, S.Williams, T. Rietman, D. Torgerson, and A. Edris "The unified power flow controller: A new approach to power transmission control," IEEE Trans. Power Del., Vol. 10, No. 2, pp.1085-1097, Apr.1995.

[32] S. D. Round, Q. Yu, L. E. Norum, and T. M. Undeland, "Performance of a unified power flow controller using a d-q control system," in Proc. 6th Int. AC and DC Power Transmission Conf., 1996, Vol. 1, No. 423.

[33] M Noroozian, L Angquist, M Ghandari and G Anderson, "Improving Power System Dynamics by Seriesconnected FACTS Devices," IEEE Transactions on Power Delivery, Vol. 12, No 4, p 1635, 1997.

[34] X. Lombard and P. Therond, "Control of unified power flow controller: Comparison of methods on the basis of a detailed numerical model," IEEE Trans. Power Syst., Vol. 12, No. 2, pp. 824-830, May. 1997.

[35] K. Smith, L. Ran, and J. Penman, "Dynamic modelling of a unified power flow controller," Proc. Inst. Elect. Eng., Gen., Transm. Distrib., Vol. 144, No. 1, pp. 7-12, Jan.1997.

[36] I. Papic, P. Zunko, D. Povh, and M.Weinhold, "Basic control of unified power flow controller," IEEE Trans. Power Syst., Vol. 12, No. 4, pp. 1734-1739, Nov. 1997.

[37] K. R. Padiyar and A. M. Kulkarni, "Control Design and Simulation of Unified Power Flow Controller," IEEE Transactions on Power Delivery, Vol. 13, No. 4,p 1348, 1998.

[38] S. Limyingcharoen, U. D. Annkkage, and N C Pahalawaththa, "Fuzzy Logic based Unified Power Flow Controllers for Transient Stability Improvement," IEE Proceeding- C, Vol. 145, No 3,p 225, 1998.

[39] H. Fujita, Y. Watanabe, and H. Akagi, "Control and analysis of a unified power flow controller," IEEE Trans. Power Electron, Vol. 14, No. 6, pp. 1021-1027, Nov. 1999. 
[40] Z. Huang, Y. Ni, C. Shen, F.Wu, S. Chen, and B. Zhang, "Application of unified power flow controller in interconnected power systems-modeling, interface, control strategy, and case study," IEEE Trans. Power Syst, Vol. 15, No. 2, pp. 817-824, May. 2000.

[41] S. Kannan, S. Jayaram, and M. M. A. Salama, "Design of a de-coupled controller for a shunt converter: Control design and performance," in Proc. 32nd North American Power Symp., Waterloo, ON, Canada, pp. 8-13, Oct. 2000.

[42] Stéphane Gerbex, Rachid Cherkaoui, and Alain J. Germond, " Optimal location of multi-type FACTS devices in Power system by means of genetic algorithm," IEEE Trans. Power Syst, Vol.16, No.3, pp. 537-544, Aug. 2001.

[43] M. Akeshita and H.Sugihara, "Effect of fault current limiting of UPFC for power flow control in loop transmission," in Proceedings of IEEEIPES Transmission and Distribution Conference and Exhibition, Japan, Oct. 2002, pp. 2032-2036.

[44] Kannan, S. Jayaram and M. Salama, "Real and reactive power coordination for a unified power flow controller," IEEE Transactions on Power Systems, Vol. 19, No. 3, pp. 1454-1461, Aug. 2004.

[45] R. Zarate-Minano, A.J.Conejo, and F.Milano, "OPFbased security redispatching including FACTS devices," IET Trans. Gen., Transmission., Distribution., Vol.2, No.
6, pp.821-833, 2008

[46] R. S. Wibowo, N. Yorino, M. Eghbal, Y. Zoka, and Y. Sasaki, "FACTS devices allocation for congestion management considering voltage stability by means of MOPSO", IEEE Transmission \& distribution conf. .Expo.: Asia and Pacific,Seoul, Korea, 2009, pp.1-4.

[47] X. Jiang, J. H. Chow, A.-A. Edris, B. Fardanesh, and E. Uzunovic, "Transfer path stability enhancement by voltage-sourced converter-based FACTS controllers," IEEE Transactions on Power Delivery, vol. 25, pp. 1019-1025, Apr. 2010

[48] R. S. Wibowo, N. Yorino, M. Eghbal, Y. Zoka, and Y. Sasaki, "FACTS Devices allocation with control coordination considering congestion relief and voltage stability," IEEE trans., on power systems, Vol. 26, No.4, Nov. 2011.

[49] J. Verveckken, F. Silva, D. Barros, and J. Driesen, "Direct Power Control of Series Converter of Unified Power-Flow Controller With Three-Level Neutral Point Clamped Converter," IEEE Transactions on Power Delivery, Vol. 27, No., pp. 1772-1782, Oct. 2012.

[50] J. Steffy Amirtham \& V. Uma M.E, "Optimal Location of Unified Power Flow Controller Enhancing System Security," IEEE Second International Conference On Science Technology Engineering and Management (ICONSTEM) , 2016, pp. 326-331. 